Role of agricultural engineering in environmental and sustainable development for the valley and delta areas: 2013 - 2032

\title{
A METHODE TO IMPROVE EVAPORATIVE COOLING SYSTEM IN GREENHOUSES UNDER HOT AND HUMID CLIMATIC CONDITIONS
}

\author{
Emad A. Almuhanna*
}

\begin{abstract}
A combining cooling system is proposed and analyzed to achieve higher cooling efficiency in hot and humid climatic conditions such as in Saudi Arabia. The system was investigating and tested under the weather conditions of Al-Ahssa, Saudi Arabia. In this paper, the results of a study on combining cooling coil unit (CCU) and direct evaporative cooling (DEC) have been discussed. The cooling effectiveness of the cooling coil unit and direct evaporative cooling systems are experimentally investigating on small greenhouse model. Total solar radiation entering the greenhouse, temperature and relative humidity of outdoor air, dry and wet-bulb temperatures of air just leaving the cooling coil unit CCU), and dry and wet-bulb temperatures of air just leaving the direct evaporative cooling system (DEC) were measured and recorded on a data-logger to analyses their correlation with the effectiveness of each cooling system. The obtained data showed that, the hourly average solar radiation flux incident outside and transmitted into the greenhouse was 555.7 and $298.7 \mathrm{~W} / \mathrm{m}^{2}$, respectively, consequently, the effective transmittance of the covering material was on the average $53.75 \%$. The temperature and relative humidity of outdoor air, respectively, were $37.3^{\circ} \mathrm{C}$ and $21.8 \%$, dry and wet-bulb temperatures just leaving the cooling coil were $29.4^{\circ} \mathrm{C}$ and $18.8^{\circ} \mathrm{C}$, respectively, and dry-bulb temperatures of air just leaving the direct evaporative cooling were $22.8^{\circ} \mathrm{C}$. The obtained results also revealed that, the overall effectiveness of the combining cooling system was more than 100\%. Thus, this system environmentally clean and energy efficient system, which considered as an alternative to the mechanical, vapour compression systems. This combining cooling system provided and maintained optimal microclimatic conditions that achieved vapour pressure deficit (VPD)
\end{abstract}

*Assistant Professor, Department of Agricultural Systems Engineering, King Faisal University, Hofuf, Saudi Arabia. 
of 0.76 and $0.40 \mathrm{kPa}$ inside the greenhouse model during daylight and at night, respectively. It can also conclude that, this combining cooling system can use in various climatic conditions as an environmentally clean and energy efficient system.

Keywords; Cooling coil unit, direct evaporative cooling, and combining cooling system.

\section{INTRODUCTION}

Tn Saudi Arabia, high air temperature $\left(\mathrm{T}>50^{\circ} \mathrm{C}\right)$ and vapour pressure deficit (VPD $>3 \mathrm{kPa}$ ) are currently observed in greenhouses during summer. These conditions are responsible for the decrease in yield and quality of greenhouse production. Thus, reducing air temperature is one of the main problems facing greenhouse management in hot and humid climates. The high heat loads (high values of outside air, dry and wet-bulb temperatures associated with high intensity of solar radiation) during summer and the aim of achieving the desired growing conditions are stimulating the use of evaporative cooling system to cool greenhouse (Arbel et al., 1999). Willits (2003) and Toida et al. (2006) showed that in the extreme environmental locations, where ambient air temperature in the summer generally exceeds $40^{\circ} \mathrm{C}$, evaporative cooling is the most efficient systems for greenhouse cooling, which can lower the inside air temperature significantly below the ambient air. These systems based on conversion of sensible heat into latent heat through the evaporation of water, which supplied mechanically. Evaporative cooling in a commercial greenhouses equipped with a pad-fan system for use during the summer period in arid countries was studied by Jamal (1994); and Jain and Tiwari (2002).

The volumetric airflow rate through the evaporative pad was determining by the number of air changes per hour and estimated that 20 number of air changes were sufficient to reach tolerable conditions inside the greenhouse under dry weather conditions. The water required for evaporative cooling is also estimating. A mathematical model was developing to estimate the water evaporation rate, airflow rate and cooling effect of an evaporative cooling system for farm structures in Saudi Arabia by Abdel-Wahab (1994). It reported that improving the cooling efficiency and covering, the roof of the greenhouse with external 
shading would save appreciable amount of energy and water consumption. Kittas et al. (2001) investigated the temperature and humidity gradients during summer in a rose production greenhouse equipped with a ventilated cooling-pad system and half shaded plastic roof. The cooling performance achieved up to $80 \%$ and temperature of the greenhouse lowered by $10^{\circ} \mathrm{C}$ than the outside air. Kittas et al. (2003) attempted to lower the air temperature in a greenhouse equipped with fan-pad cooling system by the use of partial shading on the roof to cut down the solar radiation absorption. To predict the air temperature gradients along a greenhouse, a simple climate model has proposed to incorporate the effect ventilation rate, roof shading and crop transpiration. Experimental data revealed that, the cooling system was able to keep the greenhouse air temperature at rather low levels. However, due to the significant length of the greenhouse $(60 \mathrm{~m})$, large air temperature gradients (up to $8^{\circ} \mathrm{C}$ ) was observed from the cooling pads to fans. Despite its simplicity, the model was sufficiently accurate to improve the design and the management of the cooling pad systems.

Air-condition system has become more popular and even a necessity in life not only for human but also for animal and plants to create comfortable environment, and consumed a lower amount of energy at the same time. Due to its low cost and potential high efficiency, evaporative cooling has been viewed as an attractive option, when compared with other existing ones as vapor compression, absorption/adsorption and thermoelectric refrigeration systems, for both regions with dry and hot climate and more temperate climates (Costelloe and Finn, 2003 ; Chen, 2010). Heat dissipation techniques based on the transfer of excess heat to a lower to temperature natural sinks. Regarding sky, heat dissipation is carrying out by long-wave radiation from a building to the sky that called radiative cooling. The sky equivalent temperature is usually lower than the temperature of the most bodies on the earth, therefore, any ordinary surface that interact with the sky has a net long radiant loss (Meir et al., 2003). Direct evaporative cooling is the oldest, and the most widespread form of air conditioning. The underlying principle of direct evaporative cooling is the conversion of sensible heat to latent heat. Through a direct evaporative cooling system, hot outside air passes a porous wetted 
medium. Heat energy is absorbing by the water as it evaporates from the porous wetting medium, so the air leaves the system at a lower temperature. In fact, this an adiabatic saturation process in which drybulb temperature of the air reduces as its humidity increase constant enthalpy). Some of the sensible heat of the air is transferring to the water and become as a latent heat by evaporating some of the water. The latent heat follows the water vapour and diffuses into the air. The minimum temperature that can be obtained is the wet-bulb temperature of the entering air (Camargo et al., 2005 ; Jin Guang-Yu et al., 2006 ; Wu et al., 2009). In heating, ventilation, and air conditioning (HVAC) systems, cooling coils unit (CCU) perform an essential function by exchanging the cooling load from the hot air to the chilled water loop by pushing airflow through the coil. In addition, cooling coil unit has utilized as pre-cooler systems to decrease temperature of hot air. Totally, utilization of cooling coils affects performance of HVAC systems increasingly (Jin Guang-Yu et al., 2006 ; Heidarinejad et al., 2010). Conventional evaporative cooling system can decrease the indoor air temperature theoretically approaching its wet-bulb temperature, and has used as a low energy consumed device for various cooling and air conditioning applications in industrial, agricultural and residential sectors (Costelloe and Finn, 2003). This system usually requires only a quarter of the electric power that consumed by mechanical vapor compression for air conditioning (Cerci, 2003). Therefore, such systems will help to reduce electricity requirements, and contribute to reducing greenhouse gas emissions. However, the conventional evaporative cooling system consumes a considerable amount of water during the cooling process. Al-Helal (2002) found that water consumption per $\mathrm{m}^{2}$ of cooling pad area ranged between 13.9 and $24.2 \mathrm{~L} / \mathrm{h}$ for a cross-fluted cellulose pads. From the power-demand-side, cooling equipment (fans and water pump) consumes the major power especially during extreme summer conditions where cooling is required most of the daytime. Al-Helal et al. (2004) found that fan-and-pad greenhouse evaporative cooling systems in Saudi Arabian regions consumed a maximum of $8.5 \mathrm{~W} / \mathrm{m}^{2}$ electrical powers during the daylight. 
In order to improve the performance of the evaporative cooling systems, several research papers were dedicated to explore issues about nocturnal cooling such as, Ali et al. (1995), Spronken-smith (1999), Erell and Etzion (2000), Meir et al. (2003), Bagiorgas and Mihalakakou (2007), Salim Shirazy et al. (2008), Farahani et al. (2009), and Heidarinejad et al. (2010). However, no significant investigation has been performed on combining cooling coils unit (CCU) and direct evaporative cooling system (DEC) under hot and humid climatic conditions. Thus, lack of information about feasibility of this new combination is the motivation of this study. In this research work, the water in a storage tank cooled by means of circulating the water through the cooling pads throughout the nighttime. During the next daylight, the cold water in the storage tank used in the cooling coil unit as chilled fluid to decrease temperature of outdoor air (pre-cooling). Then, the pre-cooled air with lower wet-bulb temperature passed through the direct evaporative cooling system. The performance and feasibility of such cooling system have analyzed in this paper. The vapour pressure deficit (VPD) as a good indictor of plant heat stress brought about by either excessive transpiration (high VPD values) or the inability to transpire adequately (low VDP values) has also determined.

\section{MATERIALS AND METHODS}

Reducing air temperature is one of the main problems facing greenhouse management during daylight time even in winter season such as in Saudi Arabia. Ventilation is basically used to exchange air between inside and outside of the greenhouse as a means of air temperature, relative humidity, and carbon dioxide control. The experimental work was carried out in five successive days (from 21-25 July 2010). In this research work, the system consists of three parts: (1) Greenhouse, (2) Cooling coil, and (3) Direct evaporative cooling. Each part has described in the following subsections.

\section{(1) Greenhouse}

An experimental gable-even-span greenhouse model has designed, constructed, and installed at the Agricultural and Veterinary Research Station of King Faisal University (latitude $25.4^{\circ} \mathrm{N}$, longitude $49.6^{\circ} \mathrm{E}$, and altitude $142 \mathrm{~m}$ above the sea level). The geometric characteristics of the 
gable-even-span model are as follows: eaves height $1.20 \mathrm{~m}$, gable height $0.30 \mathrm{~m}$, span angle $31^{\circ}$, width $1.0 \mathrm{~m}$, length $2.0 \mathrm{~m}$, floor surface area 2.0 $\mathrm{m}^{2}$, and volume $2.1 \mathrm{~m}^{3}$ as shown in Fig. (1). The greenhouse structural frame is formed from wooden plates $(5 \times 5 \mathrm{~cm})$. The experimental greenhouse is covered with single polyethylene sheet (PE, UV) $200 \mu \mathrm{m}$ thick. It was orientated in East-West direction, where the southern longitudinal direction faced into the sun's rays. A $60 \%$ shading black net has used to cover the roof of the green house. One extracting fan (single direct driven, $30 \mathrm{~cm}$ diameter, and $900 \mathrm{~m}^{3} / \mathrm{h}$ discharge) was located on the leeward side of the greenhouse and the cooling pads on the side toward the prevailing wind.

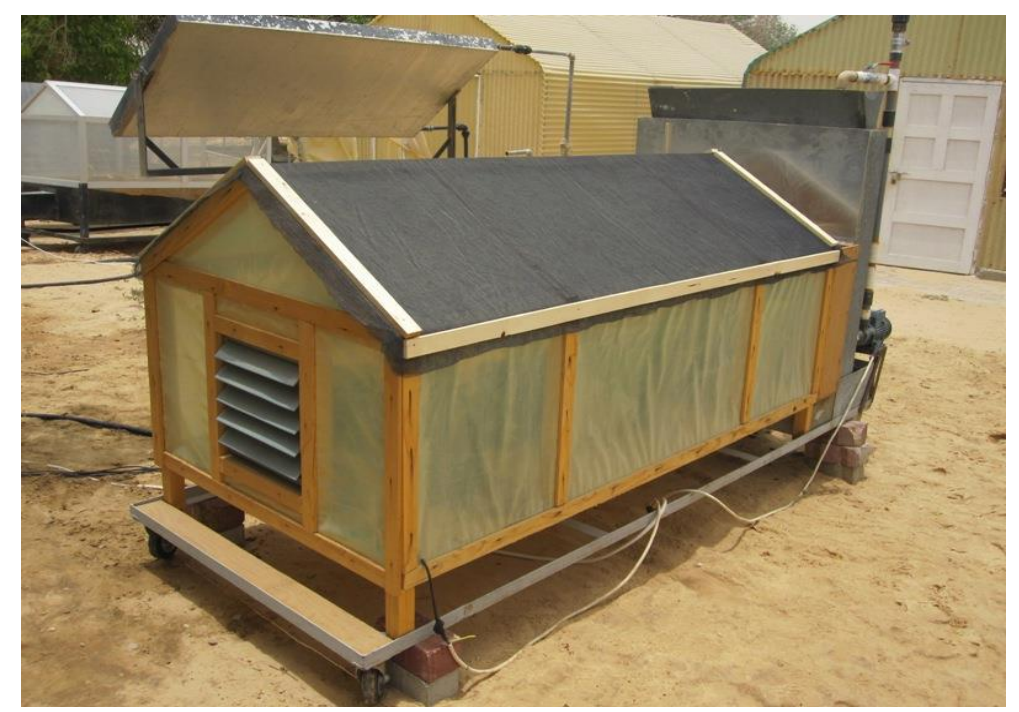

Fig. (1): Experimental gable-even-span greenhouse

\section{(2) Cooling coil unit (CCU)}

Based on the conversion of sensible heat into latent heat by means of evaporation of water supplied directly into the cross-fluted cellulose cooling pads, the collected water in the sump was allows equal to the dew point temperature of the entering air. Thus, the cold water supplied through the cooling coil during the experimental period as revealed in Fig. (2). The cooling coil consists of heat exchanger and water supplied lines installed $20 \mathrm{~cm}$ before the direct evaporative cooling system. The heat exchanger is made of 116 finned aluminum tubes arranged in 
vertical four rows. The gross dimensions of cooling coil are: $73 \mathrm{~cm}$ high, $60 \mathrm{~cm}$ wide, and $10 \mathrm{~cm}$ thick. A sensible cooling process only existed when the outer surface temperature of the coil is equal to the dew point temperature of the outdoor air. A sensible cooling process can indicate by a horizontal line (from point 1 to point 2) towards the saturation curve on the psychrometric chart as shown in Fig. (3). In other words, the humidity ratio is always constant (Wang, 2001).

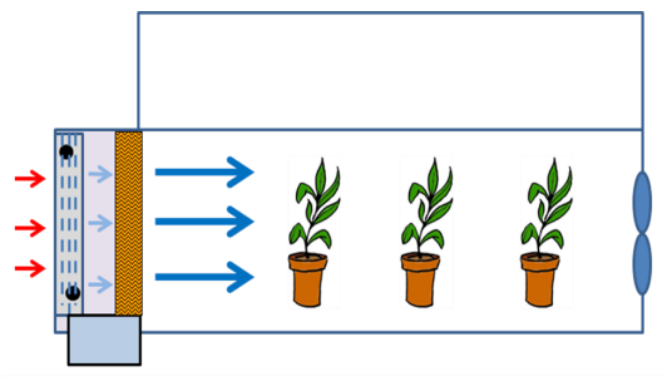

Fig. (2): Schematic diagram of combining cooling system included cooling coil unit (CCU) and direct evaporative cooling system (DEC).

\section{(3)}

\section{Direct evaporative cooling system (DEC)}

The direct evaporative cooling system (DEC) is based on the process of heat absorption during the evaporation of water supplied. It is mainly consisted of cooling pad and extracting fan. A cross-fluted cellulose pad has mounted in a vertical fashion on the side toward the prevailing wind $20 \mathrm{~cm}$ after the cooling coil unit (CCU). A cross-fluted cellulose pad having gross dimensions of $73 \mathrm{~cm}$ high, $60 \mathrm{~cm}$ wide, and $10 \mathrm{~cm}$ thick. A polyvinyl chloride pipe (12.5 $\mathrm{cm}$ diameter) has suspended directly above the cooling pad. Holes were drilled (1 mm diameter) in a line about $2 \mathrm{~cm}$ apart along the top side, and the end of this pipe was capped. A baffle has placed above the water pipe to prevent any leaking of water from the system. A sump has mounted under the cooling pad to collect the water and return it into the cooling coil and cooling pad by the water pump. In the direct evaporative cooling system, the transformation of heat and mass between air and water causes decrease in the air-dry-bulb temperature and increase in its humidity, while the enthalpy is basically constant in a perfect process. The minimum temperature that can attain is 
the wet-bulb temperature of the incoming air (point 3) as revealed in Fig. (3). Wet pad equips a water surface in which the air has humidified and the pad is wetted by dripping water.

\section{Measurements and data acquisition}

The meteorological data of the outdoor included solar radiation flux incident on a horizontal plane (Hobo Silicon Pyranometer), dry-bulb temperature (shelter and vented thermistor), wind speed and its direction (cup anemometer and wind van), and air relative humidity (hygrometer) were measured and recorded on a data-logger (Hobo data-logger- U30NRC). The air temperatures and relative humidity just leaving the cooling coil unit, just leaving the direct evaporative cooling system, and inside the greenhouse at two different locations $(100 \mathrm{~cm}$ and $180 \mathrm{~cm}$ from the cooling pad) were measured using shelted thermistor sensors and recorded on the same data-logger. The water temperature in the sump underneath the cooling pad was also measure and recorded. The data updated by a scan of all sensors every 30s and the mean of 120 scans recorded on a hard disk every hour. The wet-bulb temperatures of outdoor air, air leaving the cooling coil unit, and air leaving the direct evaporative cooling system was computed using the psychrometric program based on the dry-bulb temperature and air relative humidity.
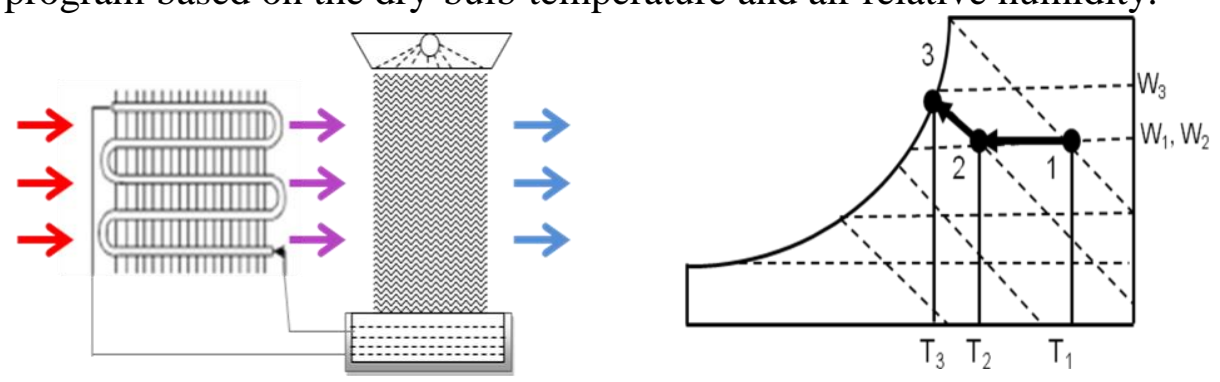

Fig. (3): Schematic diagram of two-stage cooling process included cooling coil unit and direct evaporative cooling system.

The cooling effectiveness $(\eta)$ of the cooling coil unit (CCU) and the direct evaporative cooling system (DEC) can compute by determining the mean degree of cooling $\left(\mathrm{T}_{\mathrm{ao}}-\mathrm{T}_{\mathrm{ai}}\right)$ and the wt-bulb depression $\left(\mathrm{T}_{\mathrm{ao}}-\right.$ $\mathrm{T}_{\mathrm{wb}}$ ) using the following equation (ASHRAE, 2005):- 


$$
\eta=\frac{T_{a o}-T_{a i}}{T_{a o}-T_{w b}} \times 100
$$

Where, $\mathrm{T}_{\mathrm{a}}$ and $\mathrm{T}_{\mathrm{a}}$, respectively, are the outlet and inlet dry-bulb temperatures of the air stream, and, $\mathrm{T}_{\mathrm{wb}}$, is the outlet wet-bulb temperature of the air.

\section{Vapour Pressure Deficit (VPD)}

VPD is the difference (deficit) between the amount of moisture in the air and how much moisture the air can hold when it is saturated. Therefore, VPD is a valuable way to measure greenhouse microclimatic conditions. It can use to evaluate the disease threat, condensation potential, and irrigation needs of a protected cropping. The difference between the saturation vapour pressure and the actual air vapour pressure $\left(\mathrm{VP}_{\text {sat }}-\right.$ $\mathrm{VP}_{\text {air }}$ ) is the mathematical definition of vapour pressure deficit (VPD). Higher VPD means that, the air has a higher capacity to hold water, stimulating water vapour transfer (transpiration) into the air in this low humidity condition. Lower VPD, on the other hand, means the air is at or near saturation, so the air cannot accept moisture from a leaf in this high humidity condition (Prenger and Ling, 2004). The vapour pressure deficit (VPD) can compute from the following steps:-

Where:

$$
\begin{aligned}
V P_{\text {sat }} & =\exp (Z) \\
Z & =\frac{A}{T}+\mathbf{B}+\mathbf{C T}+D T^{2}+E T^{3}+F \ln
\end{aligned}
$$

$$
\begin{array}{llll}
A & =-1.044039 \times 10^{4} & , & B=-11.294650 \\
\mathbf{C}=-2.7022355 \times 10^{-2} & , & D=1.289036 \times 10^{-5} \\
\mathbf{E} & =-2.4780681 \times 10^{-9} \quad, \quad & \mathbf{F}=6.5459673 \\
\mathbf{T} & =\text { Air temperature in }{ }^{\circ} \mathrm{R}\left({ }^{\circ} \mathrm{R}={ }^{\circ} \mathbf{F}+459.67\right)
\end{array}
$$

$$
\begin{array}{ll}
\mathbf{V P} \mathbf{P}_{\text {air }}=\left(\mathbf{V P}_{\text {sat }} \times \mathbf{R H}\right) / \mathbf{1 0 0}, & \text { psi } \\
\mathbf{V P D}=\mathbf{V P}_{\text {sat }}-\mathbf{V P}_{\text {air }}, & \text { psi }
\end{array}
$$

The values of vapour pressure deficit (VPD) can calculate in $\mathrm{kPa}$ by multiplying the values in psi in $6.894(1 \mathrm{psi}=6.894 \mathrm{kPa})$. The previous formulas have used to compute the vapour pressure deficit (VPD) using computer Excel-sheet software. 


\section{RESULTS AND DISCUSSION}

The optimization of air temperature in greenhouses is of particular importance in relation to plant growth, development, and productivity. In order to acachieve optimum microclimatic conditions, it is necessary to cool the greenhouses, particularly in hot and humid climates. Evaoprative cooling is anenvironmentally friendly and energy efficient method for cooling greenhouses in hot and dry regions. The effectiveness of combining cooling system (CCU and DEC) was investigated in particular for the hottest days during the summer (21-25 July 2010) in Saudi Arabia. The intensity of solar, air temperature, and air relative humidity inside the greenhouse model were compared with that data outside as an important measure of the effectiveness of the combining cooling system.

The data measured and recorded for a period of five days at Al-Ahssa, Saudi Arabia, used to evaluate the combining cooling system (CCU and DEC). The hourly average data are summarized and listed in Table (1). Actual solar radiation recoded outside $\left(\mathrm{R}_{\mathrm{o}}\right)$ and inside the greenhouse model $\left(R_{i}\right)$ ranged from near zero to about $1000 \mathrm{~W} / \mathrm{m}^{2}$. The lowest values recoreded during the experimental period were in the range between 25 and $100 \mathrm{~W} / \mathrm{m}^{2}$, which occurred just after sunrise and prior to sunset due to the solar altitude angle and the sky cover. The actual solar radiation recoded inside the greenhouse model was lower than that outside, due to the reflectance, absorptance, and transmittance factors of the greenhouse covering material. The hourly averages solar radiation recorded outside and inside the greenhouse model were 555.7 and $298.7 \mathrm{~W} / \mathrm{m}^{2}$, consequently, the effective transmittance of the covering material was on the average $53.75 \%$ as revealed in Fig. (4). To determine the solar radiation flux incident on a horizontal surface inside the greenhouse model $\left(\mathrm{R}_{\mathrm{i}}\right)$, all the data recorded

during the experimental period was plotted as a function of the solar radiation outside $\left(\mathrm{R}_{\mathrm{o}}\right)$ as demnostrated in Fig. (5). Regression analysis revealed a highly significant linear relationship $(\mathrm{r}=0.997 ; \mathrm{P}=0.001)$ between these parameters. The regression equation for the best fit was:

$$
\mathrm{SR}_{\mathrm{i}}=0.5478\left(\mathrm{SR}_{\mathbf{0}}\right)
$$


The regression analysis also indicated that, the solar radiation flux incident inside the greenhouse model could express as:

$$
\mathbf{S R}_{\mathbf{i}}=\tau\left(\mathbf{S R}_{\mathbf{O}}\right)
$$

Table (1): Typical data of microclimatic conditions outside and inside the greenhouse model.

\begin{tabular}{|c|c|c|c|c|c|c|}
\hline \multirow[t]{2}{*}{ Time, hr } & \multicolumn{2}{|c|}{$\begin{array}{c}\text { Solar radiation, } \\
\mathrm{W} / \mathrm{m}^{2}\end{array}$} & \multicolumn{2}{|c|}{$\begin{array}{c}\text { Air temperature, } \\
{ }^{\circ} \mathbf{C}\end{array}$} & \multicolumn{2}{|c|}{$\begin{array}{r}\text { Relative } \\
\text { hunidity, \% } \\
\end{array}$} \\
\hline & $\mathbf{S R}_{\mathbf{0}}$ & $\mathbf{S R}_{\mathrm{i}}$ & $\mathbf{T}_{\text {ao }}$ & $\mathbf{T}_{\mathbf{a i}}$ & $\mathbf{R H}_{\mathbf{o}}$ & $\mathbf{R H}_{\mathrm{i}}$ \\
\hline $\mathbf{0}$ & 0.0 & 0.0 & 31.2 & 22.8 & 30.7 & 85.2 \\
\hline 1 & 0.0 & 0.0 & 30.2 & 22.3 & 31.4 & 85.9 \\
\hline 2 & 0.0 & 0.0 & 29.3 & 21.7 & 31.5 & 87.1 \\
\hline 3 & 0.0 & 0.0 & 29.0 & 21.1 & 30.1 & 87.5 \\
\hline 4 & 0.0 & 0.0 & 28.6 & 20.7 & 29.7 & 87.7 \\
\hline 5 & 0.0 & 0.0 & 28.4 & 20.4 & 29.1 & 88.1 \\
\hline 6 & 111.6 & 41.5 & 29.8 & 20.6 & 28.8 & 86.2 \\
\hline 7 & 299.1 & 145.4 & 33.6 & 22.0 & 27.0 & 83.5 \\
\hline 8 & 510.6 & 264.6 & 37.9 & 22.6 & 22.0 & 77.3 \\
\hline 9 & 700.0 & 377.2 & 41.7 & 22.9 & 16.2 & 75.1 \\
\hline 10 & 859.7 & 472.9 & 43.6 & 23.2 & 13.2 & 72.2 \\
\hline 11 & 936.4 & 522.8 & 44.6 & 24.2 & 12.0 & 70.0 \\
\hline 12 & 951.4 & 534.4 & 45.5 & 25.0 & 11.2 & 65.5 \\
\hline 13 & 893.6 & 494.9 & 46.4 & 25.3 & 10.2 & 67.8 \\
\hline 14 & 768.6 & 421.5 & 46.5 & 25.1 & 10.0 & 70.1 \\
\hline 15 & 585.9 & 313.7 & 46.0 & 24.5 & 9.6 & 72.5 \\
\hline 16 & 387.4 & 196.3 & 45.2 & 24.4 & 9.7 & 74.3 \\
\hline 17 & 185.3 & 85.7 & 43.4 & 23.9 & 10.9 & 76.0 \\
\hline 18 & 34.1 & 11.6 & 40.6 & 23.4 & 14.8 & 77.6 \\
\hline 19 & 0.0 & 0.0 & 38.2 & 23.2 & 18.3 & 79.2 \\
\hline 20 & 0.0 & 0.0 & 36.1 & 22.8 & 24.3 & 81.5 \\
\hline 21 & 0.0 & 0.0 & 34.4 & 22.3 & 31.7 & 83.1 \\
\hline 22 & 0.0 & 0.0 & 33.2 & 22.0 & 33.1 & 83.6 \\
\hline 23 & 0.0 & 0.0 & 32.0 & 21.8 & 34.6 & 84.2 \\
\hline Mean & 555.7 & 298.7 & 37.3 & 22.8 & 21.8 & 79.3 \\
\hline
\end{tabular}




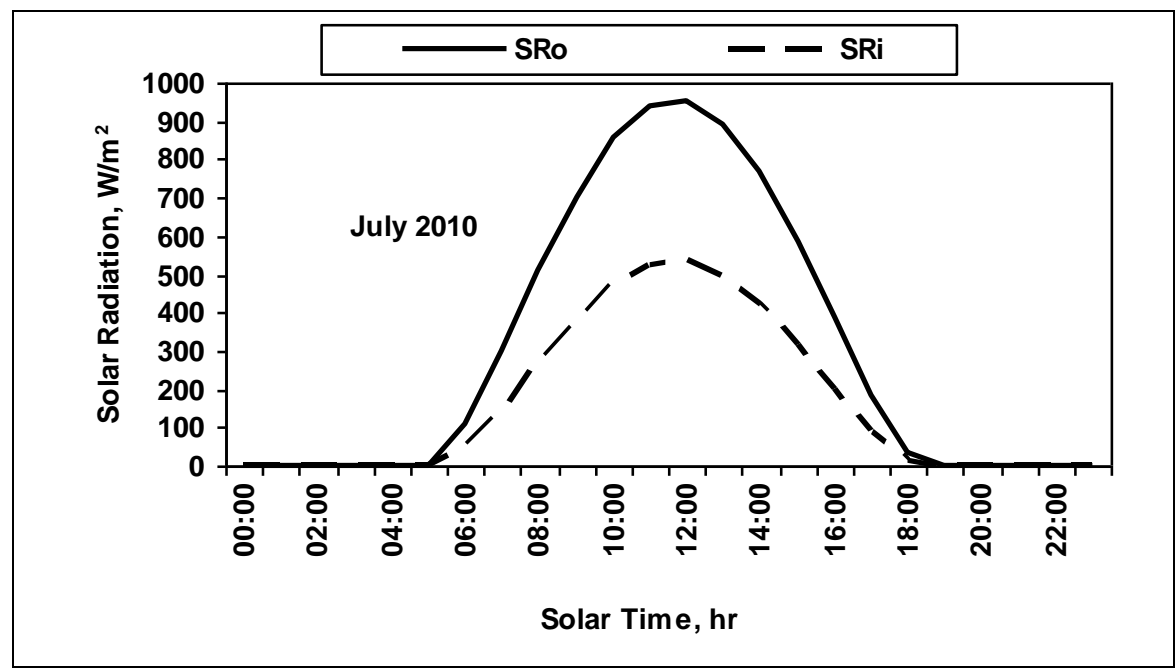

Fig. (4): Solar radiation flux incident on a horizontal surface inside and outside the greenhouse model as a function of solar time

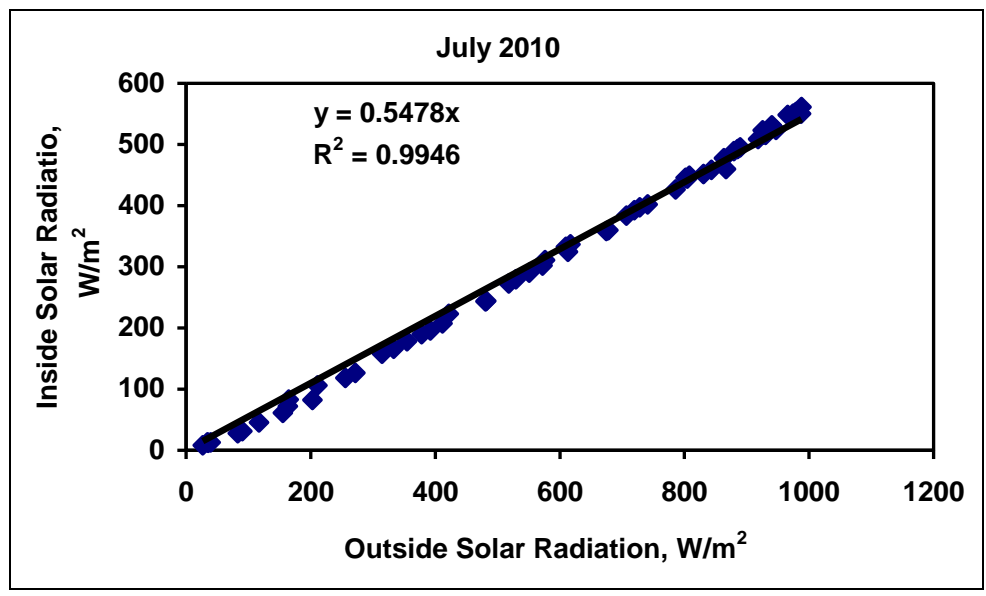

Fig. (5): Solar radiation recorded inside the greenhouse model against solar radiation outside.

Regression equation is definitely the numerical expression of the above equation. The slope is almost equal to the effective transmittance of the polyethylene and the shading black net covers $(\boldsymbol{\tau})$.

Since, air temperature and relative humidity are the two major parameters affecting thermal comfort significantly, and only sensible load can be handled by an evaporative cooling system, conventional evaporative 
cooling system is suitable for dry and temperature climate where the relative humidity is low. The air temperature just leaving the cooling coil unit (CCU) varied between 23.1 and $36.0^{\circ} \mathrm{C}$, wheares the outside air temperature ranged from 25.9 to $47.8^{\circ} \mathrm{C}$. The hourly average air temperatures recoded outside and behind the cooling coil at and around noon (critical period) were 45.5 and $35.1^{\circ} \mathrm{C}$, respectively. Accordingly, the compiled data revealed that, the cooling coil unit was an effective method for cooling air as the air temperature after passed through the CCU was lowered $10.1^{\circ} \mathrm{C}$ at that period. Based on a combining cooling system (CCU and DEC) the hourly average air temperature inside the greenhouse model was lowered $15.6^{\circ} \mathrm{C}$ blow the outside air temperature. The air temperature difference between the outside and inside varied from hour to another and during the experimental period due to effectiveness of the combined cooling system. During the critical period at and around noon this difference reached to $20.1^{\circ} \mathrm{C}$ as shown in Fig. (6). The air temperature just leaving the cooling coil unit $\left(\mathrm{T}_{\mathrm{a}, \mathrm{exch}}\right)$ was plotted against the air temperature outside the greenhouse model $\left(\mathrm{T}_{\mathrm{ao}}\right)$ to examin their relationship under Al-Ahssa city condition (Fig. 7). Regression analysis revealed a highly significant linear relationship ( $\mathrm{r}=$ $0.959 ; p=0.001$ ) between these parameters. The regrssion equation for the best fit was:

$$
\mathrm{T}_{\mathrm{a}, \mathrm{exch} .}=2.7734+0.7136\left(\mathrm{~T}_{\mathrm{ao}}\right)
$$

For the duration of the experimental period the hourly average wet-bulb depression of the outside air was $17.1^{\circ} \mathrm{C}$. According to test results, using of cooling coil unit can be provided mean degree of cooling on the average of $8.1^{\circ} \mathrm{C}$, consequently, the effectiveness of the CCU system was $47.4 \%$. The air just leaving the cooling coil unit was continuously passed through the direct evaporative cooling system in order to reduce the air temperature and at the same time increase the air relative humidity to achieve the desired level of microclimatic conditions for different plants. The hourly averages wet-bulb depression of the air just leaving the cooling coil unit (CCU) and the mean degree of cooling achieved by the direct evaporative cooling system (DEC), respectively, were $10.2^{\circ} \mathrm{C}$ and 
$7.7^{\circ} \mathrm{C}$. Consequently, the hourly average effectiveness of the direct evaporative cooling system was $75.12 \%$. A compiled information from many reasearchers (Nelson, 1996 ; Arbel et al., 1999 ; Kittas et al., 2003 ; Sethi and Sharma, 2007) reported that, the air temperature inside the greenhouse without cooling system are frequently between $11-20^{\circ} \mathrm{C}$ higher those outside in spite of open ventilators.

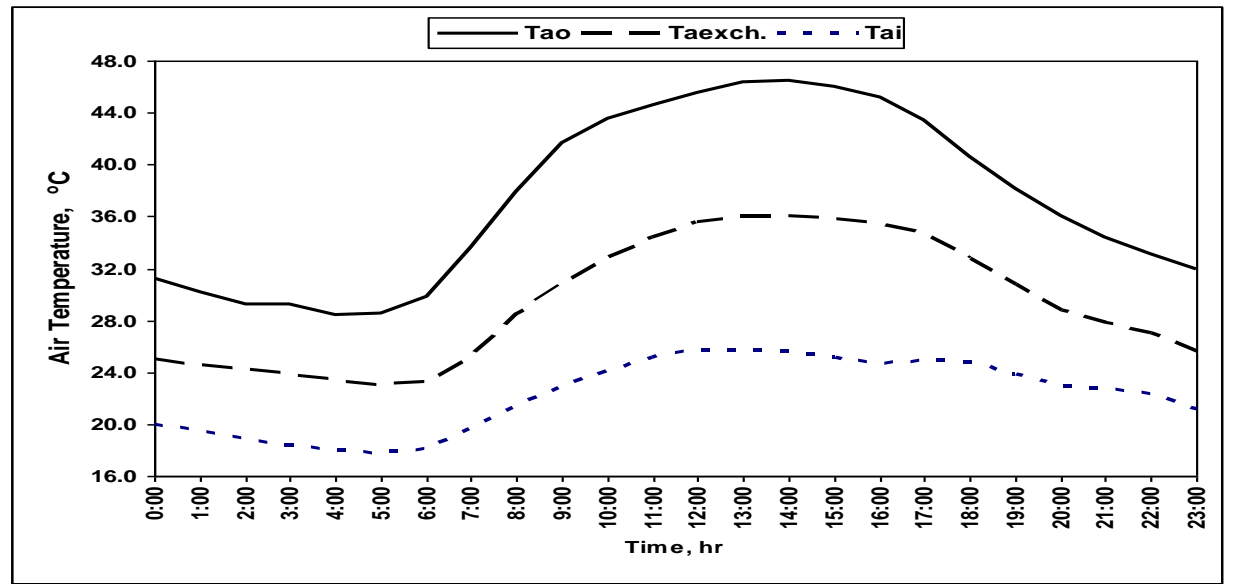

Fig. (6): Cyclic changes in air temperatures outside, after passed through the cooling coil unit (CCU), and just leaving the direct evaporative cooling system (DEC).

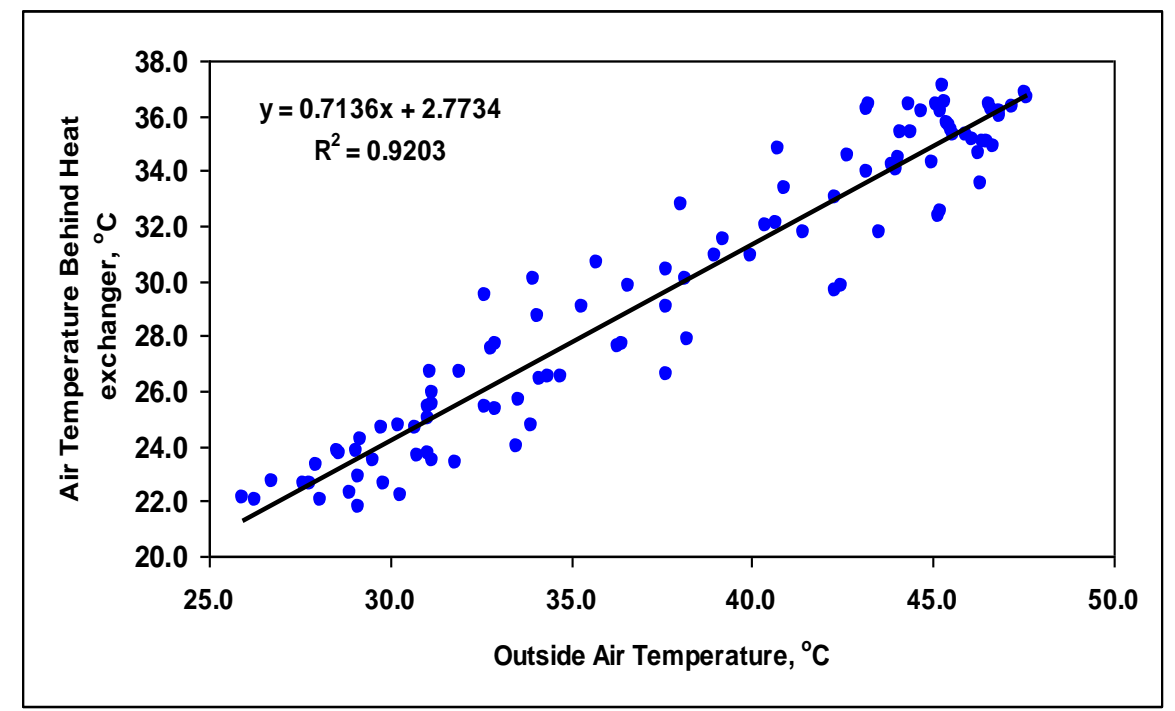

Fig. (7): Air temperatures just leaving the cooling coil unit (CCU) versus air temperature outside the greenhouse model 
The obtained results showed that, the hourly average effectiveness of the combining cooling system (CCU and DEC) during the daylight (13 hrs) was $102.8 \%$, since it achieved mean degree of cooling (air temperature depression) of $21.9^{\circ} \mathrm{C}$ at that time. Therefore, significant thermal comfort can be acieved during hot summer by combining cooling system with a great reduction of cooling load. The majorty of protected cropping can be grown well under microclimatic conditions of $25-28^{\circ} \mathrm{C}$ air temperatures and $60-65 \%$ air relative humidity (Nelson, 1996). During the daylight time, the air temperature inside the greenhouse model not exeeded $25^{\circ} \mathrm{C}$ and air relative humidity in the range between $60-70 \%$ by using the combining cooling system.

Excel-sheet software was used to calculate the vapour pressure deficit of air inside the greenhouse model during the experimental period by using the measurements of air temperature $\left(\mathrm{T}_{\mathrm{ai}}\right)$ and air relative humidity $\left(\mathrm{RH}_{\mathrm{i}}\right)$. The vapour pressure deficit during daylight time ranged from $0.33 \mathrm{kPa}$ (just after sunrise) to $1.09 \mathrm{kPa}$ (at noon) as shown in Fig. (8). The hourly average vapour pressure deficit (VPD) inside the greenhouse model during the daylight was $0.76 \mathrm{kPa}$, which computed at an average air temperature of $23.6^{\circ} \mathrm{C}$ and relative humidtity of $74.5 \%$. This range is considered as an optimal level for growing any protected cropping inside the greenhouse (Prenger and Ling, 2004). When the vapour pressure deficit of the greenhouse air is too high (VPD > $3.94 \mathrm{kPa}$ ) at air relative humidity too low $(\mathrm{RH}<35 \%)$ and air temperature very high $\left(\mathrm{T}_{\mathrm{ai}}>\right.$ $35^{\circ} \mathrm{C}$ ), the rate of evaporation from the leaves of plant can exceed the water supply into the roots system. This in turn will cause the stomata to close, and photosynthesis to slow or stop. Once the stomata close, the leaves are at risk of high temperature injury since evaporative cooling is reduced due to the lack of water to evaporate. To avoid injury and death from wilting, many plant species will either curl their leaves or orient them downward in an attempt to expose less surface area to the sun's rays. This condition can significantly downgrade the quality of potted and foliage plants and can also reduce the growth rate and quality of vegevtable crops. 


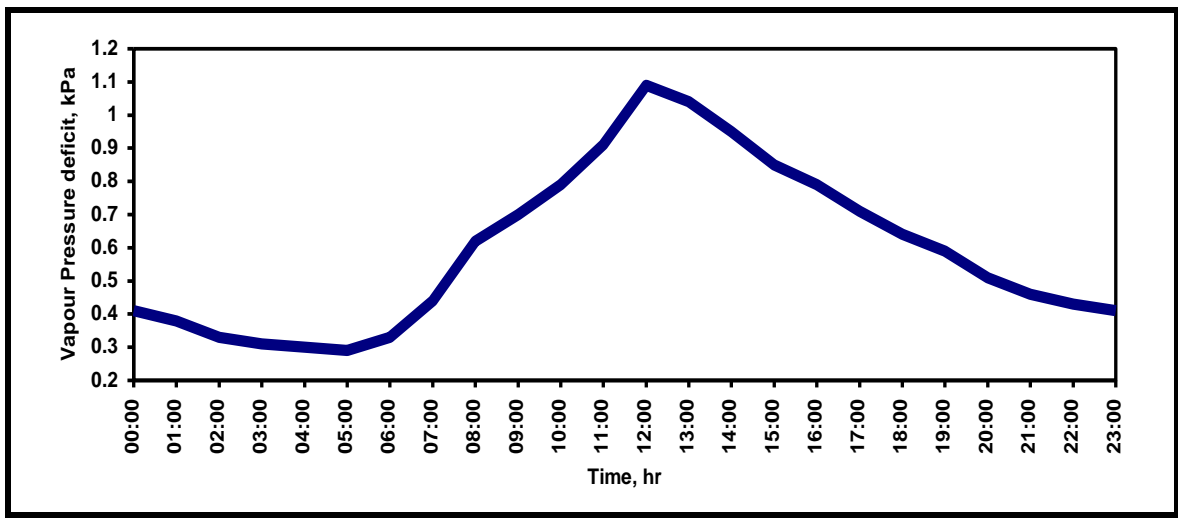

Fig. (8): Changes in vapour pressure deficit (VPD) as a function of time during the experimental period.

The vapour pressure deficit at night time ranged from $0.29 \mathrm{kPa}$ (just prior to sunrise) to $0.59 \mathrm{kPa}$ (prior to sunset) as shown in Fig. (8). The hourly average vapour pressure deficit (VPD) inside the greenhouse model at night time was $0.40 \mathrm{kPa}$, which computed at an average air temperature of $21.9^{\circ} \mathrm{C}$ and relative humidtity of $85.0 \%$. This range is also considered as an optimal level for growing any protected cropping inside the greenhouse at night time. Several studies (Bailey, 1995 ; Elad et al., 1996 ; Prenger and Ling, 2004 ; Argus, 2009) that explored disease pathogen survival at different climate levels revealed two critical values of air vapour pressure deficit. The studies showed that fungal pathogens survive best below $0.43 \mathrm{kPa}$ vapour pressure deficit. Furthermore, disease infection is most damaging below $0.20 \mathrm{kPa}$, which may occur at night time with too high air relative humidity $(\mathrm{RH}>85 \%)$ and very low air temperature $\left(\mathrm{T}_{\mathrm{ai}}<15^{\circ} \mathrm{C}\right)$. To determine the most important important parameters affecting vapour pressure deficit of greenhouse air (VPD), the air temperatures $\left(\mathrm{T}_{\mathrm{ai}}\right)$ and relative humidity $(\mathrm{RH})$ were functioned to eamine their relationships with the vapour pressure deficit. Multiple regression analysis revealed a highly significant linear relationship $(\mathrm{r}=0.997 ; \mathrm{P}=0.001)$ between these parameters. The multiple regression equation for the best fit was:

$$
\text { VPD }=2.2818-0.2968(\mathrm{RH})+0.02913\left(\mathrm{~T}_{\mathrm{ai}}\right)
$$




\section{CONCLUSION}

This research work examined the parameters that influence the level of the obtained climatic conditions and their degree of uniformity in a greenhouse model equipped with a combining cooling system (CCU and DEC). The factors that examined were; solar radiation flux incident inside the greenhouse model, air temperatures outside the greenhouse model, just leaving the cooling coil unit (CCU), and just leaving the direct evaporative cooling (DEC) system. The test also included the air relative humidity outside the greenhouse model, between the CCU and DEC, and just leaving the DEC. From this study, the following conclusion can draw as:

(1)The hourly averages solar radiation recorded outside and inside the greenhouse model were 555.7 and $298.7 \mathrm{~W} / \mathrm{m}^{2}$, consequently, the effective transmittance of the covering material was on the average $53.75 \%$.

(2)The hourly average air temperatures recoded outside and just leaving the cooling coil unit (CCU) during daylight time were 42.7 and $33.3^{\circ} \mathrm{C}$, respectively, consequently the cooling coil unit was lowered the outside air temperature by $9.4^{\circ} \mathrm{C}$. Wheares, this cooling system lowered the outside air temperaure at night time by $6.1^{\circ} \mathrm{C}$.

(3)Based on a combining cooling system (CCU and DEC) the hourly average air temperature inside the greenhouse model was lowered by $19.1^{\circ} \mathrm{C}$ and $9.0^{\circ} \mathrm{C}$ blow the outside air temperatures during daylight and at night times, respectively.

(4)It was observed that, the cooling coil unit (CCU) can be provided mean degree of cooling on the average of $8.1^{\circ} \mathrm{C}$, consequently, the effectiveness of the CCU system was $47.4 \%$. While, the hourly average effectiveness of the direct evaporative cooling system (DEC) was $75.12 \%$.

(5)A combining cooling system (CCU and DEC) provided and maintained an optimal microclimatic conditions that achieved vapour pressure defict (VPD) of $0.76 \mathrm{kPa}$ and $0.40 \mathrm{kPa}$ inside the greenhouse model during daylight and at night, respectively.

(6)This combining cooling system can be used in variuos climatic conditions as an environmentally clean and energy efficient system. 


\section{REFERENCES}

Abdel-Wahab, S. (1994) "Energy and water management in evaporative cooling system in Saudi Arabia: Resources, conservation and Recycling, 12(3-4):135-146.

Al-Helal, I. M. (2002) "Water consumption by fan-pad evaporative cooling system under arid climate conditions" Arab Universities Journal of Agricultural Science, 10(2): 429-440

Al-Helal, I. M.; Al-Abbadi, N. ; and Al-Ibrahim, A. (2004) "A study of fan-pad cooling performance for a photovoltaic powered greenhouse in Saudi Arabian summer" International Agricultural Engineering Journal, 13(4):113-124.

Arbel, A. ; Yekutieli, O. ; and Barak, M. (1999) "performance for cooling greenhouses" Journal of Agricultural Engineering Research, 72(2):129-136.

Argus Control Systems, LTD (2009) "Understanding and using VPD" Argus Application Note, Printed in Canada.

ASHRAE (2005) "Handbook of Fundamentals" American Society of Heating, Refrigerating and Air Conditioning Engineers, New York, USA.

Bailey, B. J. ; and Kano, A. (1995) "greenhouse climate control-new challenges" Acta Horticulturae, 399:13-23.

Camargo, J. R. ; Ebinuma, C. D. ; Silveria, J. L. (2005) "Experimental performance of a direct evaporative cooler operating during summer in a Brazilian city" International journal of Refrigeration, 28:1124-1132.

Cerci, Y. (2003) "A new ideal evaporative freezing cycle" International Journal of Heat and Mass Transfer, 46:2967-2974.

Costelloe, B. ; Finn, D. (2003) "Indirect evaporative cooling potential in air-water systems in temperate climates" Energy and Buildings, 35 (6):573-591.

Elad, Y. ; Malathrakis, N. E. ; and Dik, A. J. (1996) "Biological control of Botrytis-incited diseases and powdery mildews in greenhouse crops" Crop Protection, 15(3):229-238

Heidarinejad, G. ; Farahani, M. F. ; and Delfani, S. (2010) "Investigation of a hybrid system of nocturnal radiative cooling and 
direct evaporative cooling" Building and Environment, 45:15211528.

Jain, D. ; and Tiwari, G. N. (2002) "Modeling and optimal design of evaporative cooling system in controlled greenhouse" Energy Conversion and Management, 43:2235-2250.

Jamal, K. A. (1994) "Greenhouse cooling in hot countries" Energy, 19(11):1187-1192.

Jin Guang-Yu ; Cai Wen-Jian ; Wang Yao-Wen ; and Yao-Ye (2006) "A simple dynamic model of cooling coil unit" energy Conversion and Management, 47(15-16): 2659-2672.

Kittas, C. ; Bartzanas, T. ; Jaffarin, A. (2001) "Greenhouse evaporative cooling measurement and data analysis" Transactions of the ASAE, 44(3):683-689.

Kittas, C. ; Bartzanas, T. ; Jaffarin, A. (2003) "Temperature gradients in a partially shaded large greenhouse equipped with evaporative cooling pads" Bio-systems Engineering, 85(1):87-94.

Meir, M. G. ; Rekstad, J. B. ; and Lovvik, O. M. (2003) "A study of a polymer-based radiative cooling system" Solar energy, 73(6):403417.

Nelson, P. V. (1996) "Greenhouse operation and management: Fifth edition, Prentice-hall, Inc., New Jersey, 07632

Prenger, J. J. ; and Ling, P. P. (2004) "Greenhouse condensation control" understanding and using vapour pressure deficit (VPD), Fact Sheet, Ohio State University Extension, Columbus, USA.

Sethi, V. and Sharma, S. K. (2007) "Survey of cooling technologies for worldwide agricultural greenhouse application" Journal of Solar Energy, 81:1447-1459

Toida, H. ; Kozai, T. ; and Ohyama, K. (2006) "Enhancing for evaporative rate using an upward air stream to improve greenhouse-cooling performance" Bio-systems Engineering, 93(2):205-211.

Wang, S. K. (2001) "Handbook of air conditioning and refrigeration" $2^{\text {nd }}$ edition, McGraw-hill, USA

Willits, D. H. (2003) "Cooling fan ventilated greenhouse; a modeling study" Bio-Systems Engineering, 84(3):315-329. 
Wu, J. M. ; Huang, X. ; and Zhang, H. (2009) "Numerical investigation on the heat and mass transfer in a direct evaporative cooler" applied Thermal Engineering, 29:195-201.

\section{الملخص العربيى}

\section{طريقة لتحسين فاعلية نظام التبريد بالتبخير فى البيوت المحمية تحت الظروف المناخية الحارة والرئية الرئية \\ عمـاد على المهنـان}

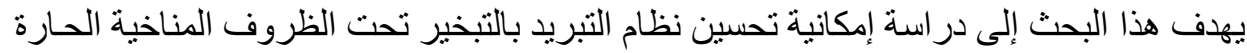

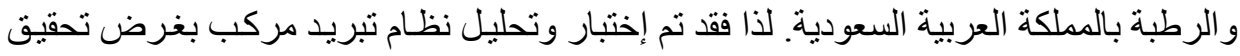

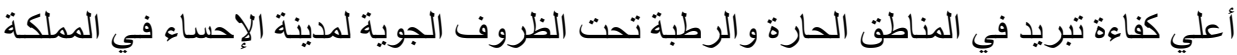

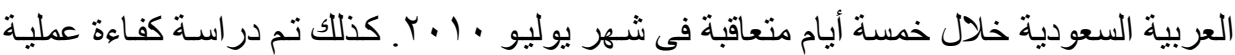

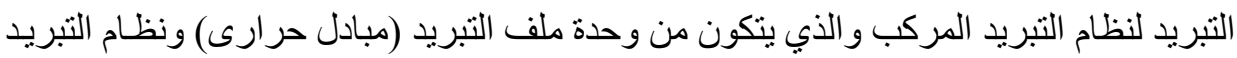

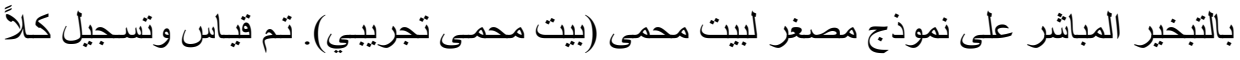

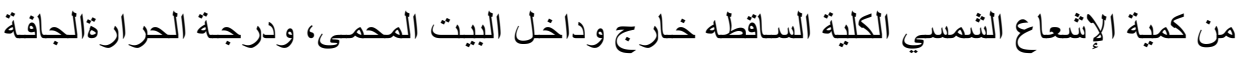

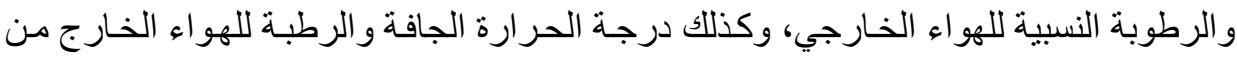

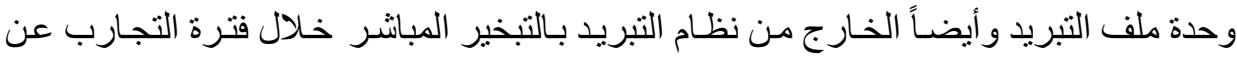

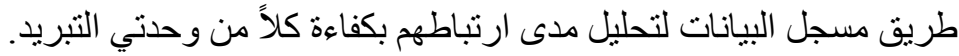

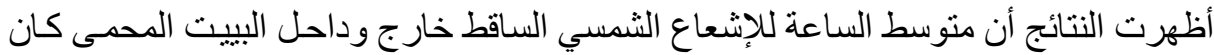
(بولى 555.7 and 298.7 W/m²

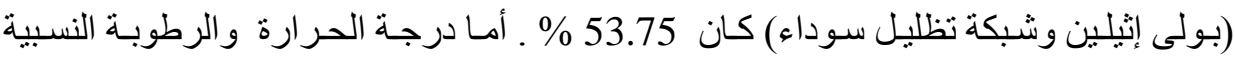

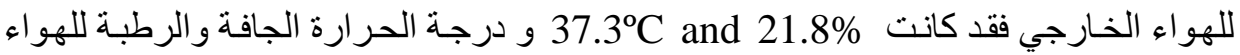

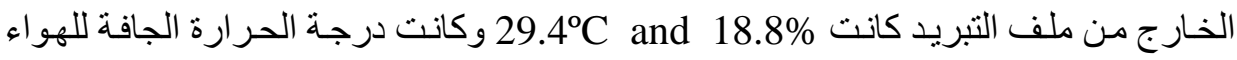

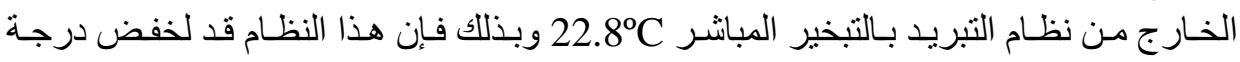

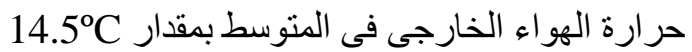

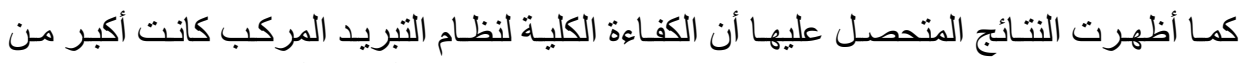

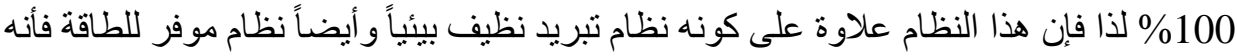

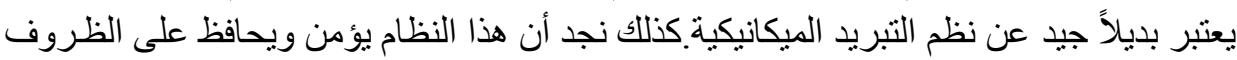

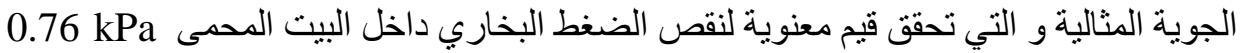

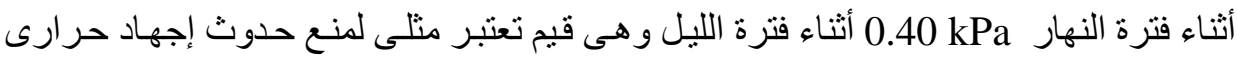

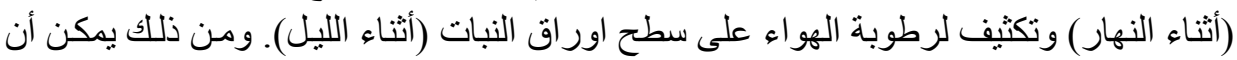

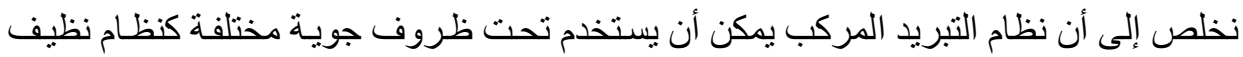
بيئياً وموفر للطاقة.

*أستاذ مساعد بقسم هندسة النظم الزر اعية - جامعة الملك فيصل - المملكة العربية السعودية. 